\title{
Imidacloprid - Induced Pathophysiological Damage in the Midgut of Locusta Migratoria (Orthoptera: Acrididae) in the Field
}

Lamia M. El-Samad

Alexandria University

Mohamed S. El-Gerbed

Alexandria University

Hanaa S. Hussein

Alexandria University

Justin Flaven-Pouchon

Eberhard Karls University Tübingen: Eberhard Karls Universitat Tubingen

Abeer El Wakil

Alexandria University

Bernard Moussian ( $\nabla$ bernard.moussian@unice.fr)

Université Côte d'Azur https://orcid.org/0000-0002-2854-9500

\section{Research Article}

Keywords: Insect, locust, neonicotinoid, detoxification, oxidative stress, ROS, midgut

Posted Date: December 6th, 2021

DOI: https://doi.org/10.21203/rs.3.rs-1088830/v1

License: (9) (i) This work is licensed under a Creative Commons Attribution 4.0 International License.

Read Full License

Version of Record: A version of this preprint was published at Environmental Science and Pollution Research on March 30th, 2022. See the published version at https://doi.org/10.1007/s11356-022-198049. 


\section{Abstract}

Neonicotinoids are modern insecticides widely used in agriculture worldwide. Their impact on target (nervous system) and non-target (midgut) tissues has been well studied in beneficial insects including honeybees. However, their effects on pest insects on the field are comparably rarely described. Here, we have studied the effects of the neonicotinoid imidacloprid on the midgut of the pest insect Locusta migratoria caught in the field. We found that in the midgut of imidacloprid-exposed locusts the activity of enzymes involved in reactive oxygen metabolism was perturbed. By contrast, the activity of P450 enzymes that have been shown to be activated in a detoxification response and that were also reported to produce reactive oxygen species was elevated. Probably as a consequence, markers of oxidative stress including protein carbonylation and lipid peroxidation accumulated in midgut samples of these locusts. Histological analyses revealed that their midgut epithelium is disorganized and that the brush border of the epithelial cells is markedly reduced. Indeed, microvilli are significantly shorter, misshapen and possibly non-functional in imidacloprid-treated locusts. We hypothesize that imidacloprid induces oxidative stress in the locust midgut, thereby changing the shape of midgut epithelial cells and probably in turn compromising their physiological function. Presumably, these effects reduce the survival rate of imidacloprid-treated locusts and the damage they cause in the field.

\section{Background}

Because of its devastating impact on agriculture, the locust Locusta migratoria migratorioides is considered the most economic important pest in Assuit governorate in Upper Egypt. The existing control methods against these pest rely on chemical insecticides such as imidacloprid, chlorpyriphos, malathion and others (El-Saad et al. 2017), which are harmful to the environment and potentially also to humans.

Since their introduction in the nineties of the last century, neonicotinoids have become the most widelyused chemical class of insecticide in many countries (Casida \&Durkin 2013, Jeschke \&Nauen 2008, Jeschke et al. 2011, Tomizawa \&Casida 2005). Due to their specificity to insects concomitant with low acute toxicity to non-insects and their versatility in application methods, neonicotinoids constitute an attractive tool in modern agriculture (Elbert et al. 2008, Thompson et al. 2020). However, concerns over neonicotinoids are emerging, and in the European Union, for instance, the use of several neonicotinoids has been widely restricted because of their adverse effects on honeybees (https://ec.europa.eu/food/plants/pesticides/approval-active-substances/renewalapproval/neonicotinoids_en) (Thompson et al. 2020, Wood \&Goulson 2017). Hence, for the next future, it is important to assess the impact of neonicotinoids and to understand their effects on the insect at the molecular and cellular levels.

Neonicotinoids target primarily at the nervous systems of insects as agonists of postsynaptic acetylcholine receptors by binding especially to the a subunits of the receptor (Buckingham et al. 1997, Matsuda et al. 2020, Suchail et al. 2004). Unlike the natural ligand of this receptor acetylcholine, neonicotinoids are not deactivated by hydrolyzation by acetylcholinesterase. Therefore, in presence of 
neonicotinoids, transmission of nerve impulses does not cease resulting in hyperexcitation of the nervous system. This neuronal dysfunction especially affects visual processing and in turn collision avoidance in, for instance, Locusta migratoria (Parkinson et al. 2017, Parkinson et al. 2020).

Commonly, exposure to toxic xenobiotics including pollutants can be monitored through their negative effects on biochemical processes in cells and tissues. Indeed, pollutants may cause variations in the activity of specific enzymes and associated cellular damages, in turn indicating the presence of these toxic pollutants (Johnston 1995, Lu et al. 2021). For instance, the upregulation of superoxide dismutase (SOD), catalase (CAT), ascorbate peroxidase (APOX), glutathione-S-transferase (GST) and lipid peroxidation have been used in ecotoxicological studies as powerful biomarkers (Scandalios 2005, Zhang et al. 2019). These biomarkers are directly or indirectly involved in reactive oxygen species (ROS) metabolism, which may be perturbed in contact to xenobiotics such as insecticides or metals in insects (El-Gendy et al. 2020). In D. melanogaster, low doses of the neonicotinoid imidacloprid cause mitochondrial dysfunction in glia cells that is associated with oxidative stress triggered by ROS (Martelli et al. 2020, Wang et al. 2018). Moreover, in insects, heat-shock proteins (HSPs) are important players in response to abiotic stressors preventing induction of cell death, for example (King \&MacRae 2015) and are therefore highly useful as biomarkers for environmental pollution (Bierkens 2000, El-Saad et al. 2017, Lewis et al. 1999). Beside these enzymatic biomarkers, the use of cellular markers provides an additional means of assessing the toxicity pollutants inside insect. One of these markers is the fragmentation of DNA in necrotic or apoptotic cells after exposure to an environmental stressor.

The cellular consequences of neonicotinoid application in insects have been largely assessed in the target tissue i.e the nervous system. The aim of the present study was to evaluate the level of protein carbonyls, lipid peroxides and antioxidant enzyme activity (SOD, CAT, APOX, GR and GPx) in the gut tissue of the locust Locusta migratoria, which inhabits sites along a gradient of imidacloprid pollution. At the cytological level, apoptosis, which is the possible consequence of perturbed ROS metabolism, was detected through flow cytometry (annexin- $V$ assay) and by transmission electron microscopy (TEM).

\section{Materials \& Methods}

\section{Insect sampling}

The study site was in Assiut governorate, the Upper Egypt (27 $10^{\prime} 48^{\prime \prime} \mathrm{N}$ and $\left.31^{\circ} 11^{\prime} 21^{\prime \prime} \mathrm{E}\right)$. The study site displayed frequent applications of neonicotinoids insecticides spraying. There are little available data in the literature regarding the existence of other contaminants in this area. Selected sprayed location was considered highly active agricultural area for maize crop.

The locust, Locusta migratoria used in the present study was collected during the summer season 2020 and placed in jars. They were kept in our laboratory cages $(40 \times 40 \times 70 \mathrm{~cm})$ under natural photoperiod conditions at relative humidity of $50-65 \%$ at $28^{\circ} \mathrm{C}$. The insects were identified for their species as $L$. migratoria at Faculty of Agriculture, Alexandria University, Egypt. L. migratoria collected from 
contaminated area were compared to those reared free of pesticide applications in the laboratory and was thus considered as the control ones.

Ten fresh specimens of each control and contaminated adult $L$. migratoria were washed with distilled water and sacrificed after anesthesia with absolute ethanol (95\%), The midguts were rapidly dissected out. Half of the sample size of the midgut tissue was stored in vials and kept at $-80^{\circ} \mathrm{C}$ until used in biochemical and neonicotinoid residue analyses and the others were used for histological and ultrastructural studies. The technique for collecting the whole midgut tissue is based on the method of Liu (Liu 1984).

\section{Determination of neonicotinoids pollutant residues}

Twenty grams of midgut tissue from control and contaminated insects were mixed with $10 \mathrm{~g}$ of anhydrous sodium sulfate and homogenized in $100 \mathrm{ml}$ of chloroform and acetone. The homogenate was acidified with 10 drops of concentrated acetic acid and filtered. The filtrate was dried by evaporation at $35^{\circ} \mathrm{C}$. The residue was redissolved in $1 \mathrm{ml}$ of $\mathrm{N}$-hexane and acetone and cleaned up using $10 \mathrm{~g}$ of $1 \%$ deactivated Florisil (Diaz et al. 2012). The samples were concentrated using a rotary evaporator to $5 \mathrm{ml}$ and completely dried under a stream of $\mathrm{N}_{2}$. The residues were dissolved in $0.5 \mathrm{ml}$ of $\mathrm{N}$-hexane. Recovery experiments of neonicotinoid named imidacloprid were carried out by using fortified samples through addition of $25 \mu \mathrm{g}$ to specimens of tissue samples. The samples were extracted, cleaned up, and determined as described before.

Then, concentrations were corrected for $100 \%$ recovery and procedural recovery trials were undertaken which were above $85 \%$. The analysis was performed on Hewlett- Packard HP-6890 series Gas Chromatograph. The injection pore and flame photometric detector, which is very sensitive to halogenated neonicotinoid, imidacloprid, were operated at 245 and $250^{\circ} \mathrm{C}$, respectively. The data were calculated to final values in parts per billion. The detection limits for the examined compounds were determined. The compound identities were accomplished by comparing retention times against pure standard of imidacloprid at the same conditions. The retention times for imidacloprid were $12.52 \mathrm{~min}$.

\section{Biochemical assays}

Antioxidant enzyme assays

The midguts of $L$. migratoria collected from control and contaminated areas were rinsed with distilled water and blotted using a filter paper. The tissues were weighed and homogenized for $30 \mathrm{~s}$ with 10 volumes (w/v) of ice-cold saline solution $(0.9 \%)$ and $40 \mathrm{mM}$ sodium phosphate with a homogenizer (Tekmar tissumizer). The homogenates were centrifuged at $6500 \mathrm{rpm}$ for $30 \mathrm{~min}$ at $4^{\circ} \mathrm{C}$ using IECCRU5000 centrifuge. The resulting supernatants were split and frozen at $-20^{\circ} \mathrm{C}$ for subsequent analysis. Glutathione (GSH) levels were assayed spectrophotometrically using the method published by Anderson (Anderson 1989). We measured the activity of superoxide dismutase (SOD) following the procedure described by Nebot et al. (Nebot et al. 1993). Catalase (CAT) activity was measured following concentration decrease of hydrogen peroxide $\left(\mathrm{H}_{2} \mathrm{O}_{2}\right)$ at $240 \mathrm{~nm}$ (Aebi 1984). To detect the activity of 
glutathione peroxidase (GPx), we monitored continuous decrease in NADPH amounts according to the method described by Chu et al. (Chu et al. 1993). GST activity was quantified by the method modified by (Carmagnol et al. 1981). Glutathione reductase (GR) was measured according to Smith et al. (Smith et al. 1988). The activity was expressed in $\mathrm{U} / \mathrm{mg}$ protein by dividing the enzyme activity per $\mathrm{ml}$ of the sample by the protein concentration in the same sample. The activity of ascorbate peroxidase (APOX) was assessed via the method reported by Levine et al. (Levine et al. 1990) .

Acetyl choline esterase assay

Acetyl choline esterase (AChE) activity was assessed in the midguts of L. migratoria tissues were measured according to Ellman et al. (Ellman et al. 1961).

Protein carbonyls and lipid peroxidase assays

We isolated the midguts of all locusts from the body and homogenized them in $5 \mathrm{~mL}$ of an ice-cold phosphate buffer with additives $(60 \mathrm{~mL}$ of $50 \mathrm{mM}$ phosphate buffer, $10 \mathrm{~mL}$ of $0.1 \%$ Triton $\times 100,5 \mathrm{~mL}$ of $0.05 \mathrm{mM} \mathrm{CaCl}$; after adjusting $\mathrm{pH}$ to 7.0 with $\mathrm{HCl}$ or $\mathrm{NaOH}$, the mixture was filled with distilled water to a volume of $100 \mathrm{~mL}$ ). After homogenization (mortar, 10 strokes $/ 30 \mathrm{~s}$ ), the samples were centrifuged at $2000 \times \mathrm{g}$ for $10 \mathrm{~min}$ at $4^{\circ} \mathrm{C}$. Then, 800 hundred $\mu \mathrm{L}$ aliquots of the supernatant were transferred to a new microtube with $800 \mu \mathrm{L}$ of $30 \%$ trichloroacetic acid (TCA). The samples were incubated for $30 \mathrm{~min}$ at room temperature and then centrifuged at $5000 \times \mathrm{g}$ for $10 \mathrm{~min}$ at $4^{\circ} \mathrm{C}$. The assay of protein carbonyls was conducted on precipitated pellets and the assay of lipid peroxides was conducted on the supernatant. The concentrations of lipid peroxides (malondialdehyde, MDA) and protein carbonyls were determined using the method of Hermes-Lima et al. (Hermes-Lima et al. 1995) and (Levine et al. 1990), respectively. The measurements were done in three replicates, each replicate was a pool of ten insects.

Cytochrome P450 monooxygenase assay

For the determination of cytochrome P450 activity, we used insect homogenates following the protocol of Brogdon (Brogdon \&Chan 2010) introducing minor modifications described in the Anopheles research of US CDC. To prepare the NaOAc buffer, we used $0.25 \mathrm{M}$ sodium acetate $\left(\mathrm{C}_{2} \mathrm{H}_{2} \mathrm{NaO}_{2}\right)$ dissolved in $800 \mathrm{ml}$ purified water; the $\mathrm{pH}$ of the solution was to 5.0 with acetic acid. Next, $20 \mathrm{mg}$ of TMBZ were dissolved in $25 \mathrm{ml}$ methanol before adding $75 \mathrm{ml}$ of $0.25 \mathrm{M} \mathrm{NaOAc}$ buffer ( $\mathrm{pH} \mathrm{5.0)}$. For the actual assay, to obtain the positive control stock solution, $10 \mathrm{mg}$ of cytochrome-C was added to $100 \mathrm{ml}$ of $0.25 \mathrm{M} \mathrm{NaOAc}$ buffer (pH 5.0). $100 \mu \mathrm{l}$ of KPO4 were pipetted to the plate with the insect homogenates in both the negative and positive sample wells. For the positive controls, $100 \mu$ of the cytochrome-C control solution was pipetted into three wells; for the actual assay, we 200 applied $\mu$ of TMBZ solution to each test well. The reactions were started by adding $25 \mu \mathrm{l}$ of $3 \%$ hydrogen peroxide $\left(\mathrm{H}_{2} \mathrm{O}_{2}\right)$. They were incubated for $5 \mathrm{~min}$ at room temperature and the OD values were recorded at $620 \mathrm{~nm}$ for determination of the oxidase activity. Cytochrome P450 (general oxidase) activity obtained from plate reading was expressed as mUnits (mU) of cytochrome P450 per milligram of protein. 


\section{Annexin V-FITC/Propidium iodide assay}

Flow cytometric analysis was performed for detecting apoptosis in the midguts tissue samples of control versus contaminated insects using a FACS Calibur flow cytometer (BD-Becton Dickinson, USA), and data were analysed using Cell Quest software (Becton Dickinson, San Jose, CA, USA). Apoptosis was assessed with flow cytometry using an annexin V-FITC/ propidium iodide (PI) staining kit (TASC annexin V-FITC, Catalog Number: TA4638). This method of apoptosis detection was based on the binding properties of annexin V to phosphatidyl serine (PS) and on the ability of PI to intercalate nuclear DNA. The percentage of apoptotic and necrotic cells was assessed from annexin-V protein binding and PI staining by flow cytometry (Shapiro 2005).

\section{Midgut histopathological examination and estimation of the mean villus length}

For histological preparations, fresh midguts tissues from control and contaminated locusts were collected and fixed in $10 \%$ buffered formalin for 24 hours. The specimens were dehydrated in increasing ethyl-alcohol concentrations (70\%, 80\%,90\%, and 100\%), double cleared in xylene for $1 \mathrm{hr}$ each, and embedded in paraffin. 4-Im-tissue sections were prepared and stained with hematoxylin and eosin (H\&E). They were examined by light microscopy and photographed. To calculate mean microvillus length for each group, ten microvilli per section were measured, and ten boundaries/slide/- locust were examined.

Scanning electron microscopic study of mid gut (SEM)

After dissection, small pieces of fresh midgut tissues were incubated in cold 4F1G for 3 hours for fixation; they were post-fixed with $2 \%$ osmium tetroxide for 2 hours at $4^{\circ} \mathrm{C}$. These samples were washed and dehydrated in an increasing series of ethanol concentration, mounted using carbon paste on an aluminum-stub and coated with gold-palladium in a sputter coating unit (JFC-1100 E). Specimens were analysed using a SEMJSM-5300 (Tahmasebi et al. 2015).

\section{Transmission electron microscopy study (TEM)}

Midguts of the control and insecticide-treated insect groups were isolated and fixed by incubation in $4 \%$ formaldehyde and $1 \%$ glutaraldehyde (4F1G) in phosphate-buffer solution (pH 7.2) at $40^{\circ} \mathrm{C}$ for $3 \mathrm{~h}$. After post-fixation in $2 \%$ osmium tetroxide $\left(\mathrm{OsO}_{4}\right)$ in the same buffer for $2 \mathrm{~h}$, samples were rinsed with the buffer. Next, samples were dehydrated in a series of increasing ethanol concentration at $40^{\circ} \mathrm{C}$. Thereafter, they were embedded in a mixture of Epon-Araldite in labeled capsules. Ultra-thin sections (0.06-0.1 $\mu \mathrm{m}$ thick) were produced from the guts of both insect groups for examination with a transmission electron microscope (TEM). Semithin sections were prepared by using LKB ultramicrotome ( $1 \mu \mathrm{m}$ thick). For quality check, determination of the orientation and structural features by light microscopy, sections were deposited on a glass slide and stained with toluidine blue. For optimal comparability, ultra-thin sections with either pale gold or silver interference color representing sections with $0.1 \mu \mathrm{m}$ or $0.06 \mu \mathrm{m}$ thickness, respectively (Peachey 1958), were chosen for further analyses. They were transferred on 200-mesh naked 
copper grids. Sections were contrasted with uranyl acetate for half an hour and lead citrate for 25-30 min (Reynolds 1963). Electron micrographs were taken at several magnifications. Observation and photographing the grids were performed on a JEOL JEM-1400 plus Electron Microscope (Jeol, Tokyo, Japan) at $80 \mathrm{kV}$ accelerating voltage, Faculty of Science, Alexandria University, Egypt.

\section{Assessment of HSP70 and HSP90 by quantitative real time PCR}

Total RNA was isolated from locust tissue samples using TRIzol reagent (Thermo Fisher Scientific, USA). Sample RNA concentrations were evaluated using a NanoDrop 2000 spectrophotometer (Thermo Fisher Scientific, USA) at $260 \mathrm{~nm}$. After that, total RNA (1.0 $\mu \mathrm{g}$ per sample) was treated with DNase I (Fermentas, USA) to remove potential genomic DNA contamination, first-strand cDNA was synthesized in a $20 \mu \mathrm{L}$ reaction system using a High-Capacity cDNA Reverse Transcription Kit (Thermo Fisher Scientific, USA).

The relative expression levels of the HSP70 and HSP90 in locust tissues were analyzed using qRT-PCR. 1 $\mu \mathrm{g}$ RNA was used as the template. Specific primers for HSP70, HSP90 and the housekeeping gene $\beta$-actin used in the assay are listed in the table below (Wang et al. 2006). qRT-PCR reactions were executed using Qiagen Rotor-Gene SYBR Green PCR Kit in a $25 \mu \mathrm{L}$ mixture containing $1 \mu \mathrm{L}$ of cDNA, $12.5 \mu \mathrm{L}$ of SYBR Green, $2.5 \mu \mathrm{L}$ of each primer, and $9 \mu \mathrm{L}$ of $\mathrm{H}_{2} \mathrm{O}$. The qRT-PCR program consisted of an initial step at $95^{\circ} \mathrm{C}$ for $5 \mathrm{~min}$, followed by 40 cycles of $95^{\circ} \mathrm{C}$ for $15 \mathrm{~s}$ and $60^{\circ} \mathrm{C}$ for $10 \mathrm{~s}$. The assays were run in the Rotor-Gene Q using Rotor-Gene Q-Pure Detection version 2.1.0 (Qiagen, USA). Quantification of the transcript level of HSP70 and HSP90 mRNA was completed using the comparative 2- $\triangle$ CT method (Livak \&Schmittgen 2001). The identification was performed using primers 5'-AAA ATG AAA GAA ACG GCA GAG G-3' (forward), 5'-TAA TAC GCA GCA CAT TGA GAC C-3' (reverse) for HSP70, 5'-GAT ACA TCC ACA ATG GGC TAC A-3' (forward), 5'-CTT GTC ATT CTT GTC CGC TTC A-3' (reverse) for HSP90, and 5'-AAT TAC CAT TGG TAA CGA GCG ATT-3' (forward), 5'-TGC TTC CAT ACC CAG GAA TGA-3' (reverse) for $\beta$ actin.

\section{Statistical analysis}

Enzymatic activities and gene expression were measured in biological triplicate. Student tests were performed after checking homoscedasticity with Fisher exact tests between treatments and controls. Data were analyzed using XIstat (c) 2010 from Addinsoft.

\section{Results}

\section{Neonicotinoids are present in the locust midgut}

Locusts caught in the field have been exposed to the neonicotinoid imidacloprid (Fig. 1). In other insects, it has been proposed that complex changed acetylcholine esterase may be a biomarker for neonicotinoid exposure (Morakchi et al. 2005). To evaluate imidacloprid exposure of our field locusts, we therefore determined the activity of acetylcholine esterase (AChE). In a specific enzyme activity assay, we found 
that AChE performance is significantly reduced by $40 \%$. As caught locusts were viable, this result is consistent with a sub-lethal exposure of these locusts to imidacloprid.

\section{Imidacloprid deactivates ROS removal in the midgut}

Neonicotinoid processing involves ROS production (Martelli et al. 2020). We analyzed ROS metabolism in our field locust population by measuring the activity of a series of reactions catalyzed by enzymes involved in the oxidative stress response also in insects including catalase (CAT), superoxide reductase (SOD), glutathione reductase (GR), glutathione S-transferase (GST), guaiacol peroxidase (GPX) and ascorbate peroxidase (APOX) (Fig. 2) (Cui et al. 2020). In addition, we determined the amounts of reduced glutathione (GSH), protein carbonylation (PC) and malondialdehyde (MDA) as markers of oxidative stress (I. et al. 2003). The activities of CAT, SOD, GR, GPX and APOX were substantially reduced in imidacloprid treated animals. These results suggest that imidacloprid induces oxidative stress. Consistently, GST activities and MDA, PC and GSH amounts were increased in these locusts.

Detoxification upon exposure to xenobiotics including insecticides imidacloprid is to a large extent managed by $\mathrm{P} 450$ cytochromes that in redox reactions participate at the xenobiotic metabolism. We found that P450 cytochrome activity in increased in the gut as well as the ovaries (Fig. 2). We conclude that imidacloprid triggers detoxification via enhancing the activity of P450 cytochromes.

Next, we monitored the expression of hsp70 and hsp90, two genes coding for chaperones that assist protein folding under stress conditions among other in the nervous system (Lackie et al. 2017). The expression of both genes is elevated suggesting that imidacloprid treated animals launch a program to alleviate the effects of the insecticide (Fig. 2). However, together, these results indicate that despite of an activated detoxification response, imidacloprid causes oxidative stress.

A consequence of oxidative stress is apoptosis. By flow cytometry (comet assay), we detected apoptosis by marking midgut cells of control and imidacloprid-exposed locusts with annexin-FITC and propidium iodide (Fig. 3). The ratio of apoptotic to non-apoptotic cells was significantly increased in imidaclopridtreated animals. This finding indicates that imidacloprid induces apoptosis in midgut cells of field locusts.

\section{Microvilli structure and density is compromised upon imidacloprid application}

In various insect species including the honeybee Apis mellifera and the silkworm Bombyx mori neonicotinoids have been shown to affect midgut function (Arthidoro de Castro et al. 2020, Wang et al. 2020). To evaluate the impact of imidacloprid on the locust midgut, we examined the ultrastructure of midgut cells by light and electron microscopy.

Sections of control adult desert locust midgut are illustrated in Fig. 4A-E. Images from the control group revealed a cylindrical simple tube of regular thickness with a single layer of epithelial cells (Fig. 4A). Three types of epithelial cells were found throughout the epithelial layer of the midgut (Fig. 4B-E): 1) 
Columnar digestive cells, the most common cell type that can be recognized by their light staining; these cells produce regular microvilli at their apical site forming the brush border that faces the gut lumen. Their nuclei are oval containing electron-dense chromatin. This layer is supported by the basal lamina and enveloped by a thin bipartite layer of visceral muscles consisting of an inner circular muscle and an outer longitudinal muscle. 2) Regenerative cells with a basophilic cytoplasm and a spherical nucleus cluster together forming distinct nests (nidi) distributed regularly in the basal region of the digestive and secretory cells. Basally, they are delimited by the basement membrane and do not participate at the formation of the luminal surface. 3) The cylindrical or drop-shaped endocrine cells contact the basal lamina via a long, thin cytoplasmic protrusion while their apical membrane does not join the midgut luminal surface. They insert individually between the digestive cells (nidi). Their nuclei usually localize to the periphery of the niches.

Transverse sections of treated adult desert locust midgut are shown in Fig. 5A-E. Partly, midgut epithelial cells are organized normally, while other parts of the midgut display severe alterations including disrupted epithelial cells, whose debris was found in the midgut lumen. Digestive cells, usually columnar, were rather short containing higher amounts of vacuoles in the cytoplasm; often, their nuclei localized to the midgut lumen. Some cells formed irregularly structured microvilli with reduced tips; occasionally microvillar material budded into the organ lumen due to cell swelling and vacuolization; in some regions, the brush border was completely absent. The lumen shape was irregular because of longitudinal infoldings. The basal lamina and the visceral muscle layer were both thin and, in some parts of the midgut, separated from the epithelium. Regenerative cells were deformed and occasionally surpassed the apical surface of the epithelium; nidi were disorganized and difficult to identify (Figs. 5D and 6B-C).

In SEM micrographs of the control midgut, the brush border with the regularly organized microvilli formed a smooth lumen surface. By contrast, the apical cell surfaces of the midgut of imidacloprid-treated locusts were irregular (Fig. 7A\&B). Moreover, determination of microvillus length ( $\mu \mathrm{m} \pm \mathrm{SE}$ ) revealed a significant decrease $(P<0.05)$ in the length of microvilli in the imidacloprid-contaminated locust midgut compared to the control (Fig. 8).

To gain a more detailed image of the midgut of control and imidacloprid-treated locusts, we analysed their ultrastructure by TEM. In these micrographs, the midgut is composed of a single layered epithelium supported by a thin and continuous basal lamina or basement membrane. The basal part of the cells forms the basal labyrinth of in-folding of the basal cell membrane. The apical membrane builds wellorganized microvilli with regular thickness and lengths that line the lumen of the gut. At their tips, microvilli may possess vesicle-like or bleb-like structures, which reflect secretory activity. The nuclei generally lie in the middle of digestive cells, but occasionally, they may be shifted basally or apically. Their shape is ovoid and they contain distinct heterochromatin (Fig. 8A\&B). Numerous elongated mitochondria with outlined membranes encasing the dense matrix with cristae occupy the middle and apical cytoplasm. Cisternae of the rough endoplasmic reticulum and Golgi complexes are found randomly in the cytoplasm. We observed numerous small vesicles with electron-dense material, and a few lysosomes in the cytoplasm (Fig. 8C\&D). The regenerative cells with irregular contours and round or 
ovoid nuclei characterized by disperse euchromatin and at least one electron-dense nucleoli form the nidi. Finally, the endocrine cells in-between the digestive cells that are slim contacting the basement membrane and the gut lumen. They contain a deformed nucleus, a few mitochondria, rough endoplasmic reticulum and a Golgi apparatus.

In the midgut epithelium of imidacloprid-treated adult desert locusts, the columnar digestive cells display a comparably high vacuolization of the basal cytoplasm and have an irregularly shaped nucleus with a nucleolus and fragmented heterochromatin. The brush border of these cells is disorganized, the microvilli are irregularly thick and distorted. Mitochondria are not uniformly shaped and have altered cristae; they do accumulate at the apical periphery but are distributed throughout the cell (Fig. 8A and B). Membranes representing rough endoplasmic reticulum were bloated and short, fragmented cisternae were observed in the apical portion of the cell. In addition to these structures, we found a few lipid droplets and some lysosomes in these cells. Interestingly, we identified many autophagic vacuoles in imidacloprid-treated locusts. Regenerative cells were deformed and protruded from the surface into the lumen; the nests of regenerative cells were disorganized, reduced in size and number. Closer examinations of the regenerative cells revealed features of necrosis, which is indicated by nuclei with corrugated nuclear membranes, formation of myelinic structures, a few mitochondria, smooth endoplasmic reticulum, a few lipid droplets and various-sized lysosomes (Fig. 8C\&D). The ultrastructural changes of the midgut epithelial cells in control and imidacloprid-treated adult L. migratoria are summarized in Table 1. 
Table 1

Summary of ultrastructural changes of the midgut epithelial cells in control and treated old adult $L$. migratoria.

\begin{tabular}{|lll|}
\hline \multicolumn{1}{|l}{$\begin{array}{l}\text { Shape of epithelial } \\
\text { cells }\end{array}$} & Columnar & Treated \\
\hline microvilli & $\begin{array}{l}\text { Well-developed and continuous throughout the } \\
\text { apex of the cell }\end{array}$ & $\begin{array}{l}\text { Packed, missing in some } \\
\text { regions }\end{array}$ \\
\hline Cytoplasm & Dense and granular & Less granular \\
\hline Nucleus & Oval & Round, Elongated \\
\hline $\begin{array}{l}\text { State of } \\
\text { mitochondria }\end{array}$ & Normal with cristae well developed & $\begin{array}{l}\text { Swollen, many in process } \\
\text { of lysis }\end{array}$ \\
\hline $\begin{array}{l}\text { Distribution of } \\
\text { mitochondria }\end{array}$ & $\begin{array}{l}\text { Lying mostly in the apical and basal regions of } \\
\text { the cell }\end{array}$ & $\begin{array}{l}\text { Scattered throughout the } \\
\text { cell }\end{array}$ \\
\hline $\begin{array}{l}\text { Endoplasmic } \\
\text { reticulum }\end{array}$ & organized with ribosomes & Less dense and dilated \\
\hline Golgi complex & Well-developed & Present \\
\hline Lysosome & Present & Present \\
\hline Lipid bodies & Present (few) & Present \\
\hline Autophagic vacuoles & Present & Many in numbers \\
\hline
\end{tabular}

\section{Discussion}

\section{Field locusts are exposed to sub-lethal concentrations of imidacloprid}

Upon uptake by feeding, xenobiotics travel through the digestive track passing different types of cells. In this work, we show that field captured locusts display a physiological and morphological response to imidacloprid exposure.

Expectedly, imidacloprid-treated locusts have a lowered AChE activity. As neonicotinoids cause an immediate paralysis and death of the insect (Bass \&Field 2018), we conclude that imidacloprid concentrations in our field caught animals was sub-lethal. Sub-lethal effect of neonicotinoids including imidacloprid have been reported for a number of insect species especially in the honeybees Apis mellifera or cerana and the model insect Drosophila melanogaster (Delkash-Roudsari et al. 2020, Martelli et al. 2020). In the honeybee chronic exposure to low imidacloprid concentration interferes with learning and locomotion (Delkash-Roudsari et al. 2020, Gao et al. 2020). In D. melanogaster, low imidacloprid 
concentrations induce production of ROS that in turn causes neurological and metabolic defects (Martelli et al. 2020).

\section{The midgut is a target of imidacloprid}

An organ recurrently affected by neonicotinoids including imidacloprid is the locust midgut. In various insect species such as Apis mellifera (honeybee), Melipona quadrifasciata (a wild bee), Podisus nigrispinus (a predatory bug) and Bombyx mori (silkworm) especially low concentrations of imidacloprid or acetamiprid cause, among others, reduction and malformation of the microvilli. Defective microvilli may, in turn, impede food processing and thereby reduce insect fitness. The midgut phenotype seems not to be specific to imidacloprid or neonicotinoids in general. Application of chlorantraniliprole, for instance, that does not belong to the neonicotinoid class of insecticides and acts on the insect ryanodine receptor, causes similar defects in the midgut of Anticarsia gemmatalis, a moth (Castro et al. 2019). The pyrethroid insecticide lambda-cyhalothrin also impacts, among other organs, on the midgut of honeybee workers (Arthidoro de Castro et al. 2020). Thus, the non-primary target organ midgut seems to be sensitive to the function of some unrelated insecticides. What could be the mechanism? The nervous system or muscles are the primary target organ of most insecticides including neonicotinoids, pyrethroid and chlorantraniliprole. As a composite organ, the midgut is surrounded by muscles that are enervated by neurons. In a simple and speculative scenario, hence, perturbed interaction of the midgut cells with muscles and nerve cells may be the reason for midgut cell deformations and malfunction. Alternatively, direct physiological consequences of insecticide function may explain the defects observed in the midgut.

\section{Imidacloprid perturbs ROS metabolism in field locusts}

Indeed, we found that imidacloprid caused a change in the activity of enzymes that are involved in ROS metabolism. Enzymes needed to eliminate ROS showed lower activity, while molecular responses to elevated ROS levels such as protein carbonylation were enhanced. What is the underlying molecular mechanism? In insects, xenobiotics including insecticides have been repeatedly shown to induce ROS production (Palli 2020). To some extent, hence, the adverse effects of insecticides are not only due to their inhibitory function on their direct target, but also on their capability to promote ROS production that is accompanied by the detoxification program triggered by the contact of the organism with the insecticide. Several pathways are induced in this process (Amezian et al. 2021). Commonly, they regulate the expression of genes coding for detoxification enzymes including P450s that are involved in redox reactions. Consistently, in our field locusts exposed to imidacloprid the activity of P450 enzymes is elevated both in the intestines and the ovaries. P450s are known to generate ROS (Li et al. 2021); together with the observation that the activity of those enzymes eliminating ROS declined in our field animals, we believe that due to hyperactivity of P450 enzymes our locusts suffer massive oxidative stress that in turn may be responsible for cell degeneration in the midgut. Indeed, we detected higher levels of apoptotic cells in locusts exposed to imidacloprid than in control locusts. Our data underline that these defects are not only accessible to experimental setups in the laboratory but also in the field where the actual insecticide-insect interaction takes place during pest management. 


\section{Declarations}

\section{Ethical approval and consent to participate}

Not applicable

\section{Consent for publication}

All authors have read the manuscript and agree for publication.

\section{Availability of data and materials}

Raw data and all materials are available upon request.

\section{Declaration of competing interest}

The authors declare that they have no known competing financial interests or personal relationships that could have appeared to influence the work reported in this paper.

\section{Funding}

The contribution of BM was financed by the German Research Foundation (DFG M01714/9).

\section{Authors' contributions}

L.M.E-S. Conceptualization, Project administration, Validation, Formal analysis, Supervision, Revising the draft, M.S. E-G. Methodology, Formal analysis, Data curation, Revising the draft, H.S.H. Methodology, Formal analysis, Data curation, Revising the draft, J F-P Formal statistical analysis, Data curation, Revising the draft, A.E.W. Project administration, Validation, Supervision, Reviewing \& editing the draft, B.M. Validation, Formal statistical analysis, Data curation, Writing - original draft, Reviewing \& Editing the draft.

\section{Acknowledgements}

Not applicable.

\section{References}

1. Aebi H (1984) Catalase in vitro Methods Enzymol. 105:121-126. Find this article online 
2. Amezian D, Nauen R, Le Goff G (2021) Transcriptional regulation of xenobiotic detoxification genes in insects - An overview. Pestic Biochem Physiol 174:104822

3. Anderson M (1989) : Enzymatic and chemical methods for the determination of glutathione. Glutathione: chemical, biochemical and medical aspects, 339-365

4. Arthidoro de Castro MB, Martinez LC, Cossolin JFS, Serra RS, Serrao JE (2020) Cytotoxic effects on the midgut, hypopharyngeal, glands and brain of Apis mellifera honey bee workers exposed to chronic concentrations of lambda-cyhalothrin. Chemosphere 248:126075

5. Bass C, Field LM (2018) Neonicotinoids Curr Biol 28:R772-R773

6. Bierkens JG (2000) Applications and pitfalls of stress-proteins in biomonitoring. Toxicology 153:6172

7. Brogdon W, Chan A (2010) Guidelines for evaluating insecticide resistance in vectors using the CDC bottle bioassay/methods in Anopheles research. CDC Atlanta USA CDC Tech Rep 1:1-28

8. Buckingham S, Lapied B, Corronc H, Sattelle F (1997) Imidacloprid actions on insect neuronal acetylcholine receptors. J Exp Biol 200:2685-2692

9. Carmagnol F, Sinet PM, Rapin J, Jerome H (1981) Glutathione-S-transferase of human red blood cells; assay, values in normal subjects and in two pathological circumstances: hyperbilirubinemia and impaired renal function. Clin Chim Acta 117:209-217

10. Casida JE, Durkin KA (2013) Neuroactive insecticides: targets, selectivity, resistance, and secondary effects. Annu Rev Entomol 58:99-117

11. Castro B, Martinez LC, Plata-Rueda A, Soares MA, Tavares WS, Serrao JE, Zanuncio JC (2019) Chlorantraniliprole degenerates microvilli goblet cells of the Anticarsia gemmatalis (Lepidoptera: Noctuidae) midgut. Chemosphere 229:525-528

12. Chu F-F, Doroshow JH, Esworthy RS (1993) Expression, characterization, and tissue distribution of a new cellular selenium-dependent glutathione peroxidase, GSHPx-GI. J Biol Chem 268:2571-2576

13. Cui X, Wang C, Wang X, Li G, Liu Z, Wang H, Guo X, Xu B (2020) Molecular Mechanism of the UDPGlucuronosyltransferase 2B20-like Gene (AccUGT2B20-like) in Pesticide Resistance of Apis cerana cerana. Front Genet 11:592595

14. Delkash-Roudsari S, Chicas-Mosier AM, Goldansaz SH, Talebi-Jahromi K, Ashouri A, Abramson Cl (2020) Assessment of lethal and sublethal effects of imidacloprid, ethion, and glyphosate on aversive conditioning, motility, and lifespan in honey bees (Apis mellifera L.). Ecotoxicol Environ Saf 204:111108

15. Diaz P, Jeong SC, Lee S, Khoo C, Koyyalamudi SR (2012) Antioxidant and anti-inflammatory activities of selected medicinal plants and fungi containing phenolic and flavonoid compounds. Chin Med $7: 26$

16. El-Gendy AH, Augustyniak M, Toto NA, Al Farraj S, El-Samad LM (2020) Oxidative stress parameters, DNA damage and expression of HSP70 and MT in midgut of Trachyderma hispida (Forskal, 1775) (Coleoptera: Tenebrionidae) from a textile industry area. Environ Pollut 267:115661 
17. El-Saad AM, Kheirallah DA, El-Samad LM (2017) Biochemical and histological biomarkers in the midgut of Apis mellifera from polluted environment at Beheira Governorate, Egypt. Environ Sci Pollut Res Int 24:3181-3193

18. Elbert A, Haas M, Springer B, Thielert W, Nauen R (2008) Applied aspects of neonicotinoid uses in crop protection. Pest Manag Sci 64:1099-1105

19. Ellman GL, Courtney KD, Andres V Jr, Featherstone RM (1961) A new and rapid colorimetric determination of acetylcholinesterase activity. Biochem Pharmacol 7:88-95

20. Gao J, Jin SS, He Y, Luo JH, Xu CQ, Wu YY, Hou CS, Wang Q, Diao QY (2020) : Physiological Analysis and Transcriptome Analysis of Asian Honey Bee (Apis cerana cerana) in Response to Sublethal Neonicotinoid Imidacloprid. Insects 11

21. Hermes-Lima M, Willmore WG, Storey KB (1995) Quantification of lipid peroxidation in tissue extracts based on Fe (III) xylenol orange complex formation. Free Radic Biol Med 19:271-280

22. Rossi ID-D, Giustarini R, Milzani D, Colombo A R (2003) Protein carbonyl groups as biomarkers of oxidative stress. Clin Chim Acta 329:23-38

23. Jeschke P, Nauen R (2008) Neonicotinoids-from zero to hero in insecticide chemistry. Pest Manag Sci 64:1084-1098

24. Jeschke P, Nauen R, Schindler M, Elbert A (2011) Overview of the status and global strategy for neonicotinoids. J Agric Food Chem 59:2897-2908

25. Johnston G (1995) The study of interactive effects of pollutants: a biomarker approach. Sci Total Environ 171:205-212

26. King AM, MacRae TH (2015) Insect heat shock proteins during stress and diapause. Annu Rev Entomol 60:59-75

27. Lackie RE, Maciejewski A, Ostapchenko VG, Marques-Lopes J, Choy WY, Duennwald ML, Prado VF, Prado MAM (2017) The Hsp70/Hsp90 Chaperone Machinery in Neurodegenerative Diseases. Front Neurosci 11:254

28. Levine RL, Garland D, Oliver CN, Amici A, Climent I, Lenz A-G, Ahn B-W, Shaltiel S, Stadtman ER (1990) [49] Determination of carbonyl content in oxidatively modified proteins. Methods Enzymol 186:464478

29. Lewis S, Handy RD, Cordi B, Billinghurst Z, Depledge MH (1999) Stress proteins (HSP's): Methods of Detection and Their Use as an Environmental Biomarker. Ecotoxicology 8:351-368

30. Li X, Deng Z, Chen X (2021) Regulation of insect P450s in response to phytochemicals. Curr Opin Insect Sci 43:108-116

31. Liu T (1984) Ultrastructure of the midgut of the worker honey bee Apis mellifera heavily infected with Nosema apis. J Invertebr Pathol 44:282-291

32. Livak KJ, Schmittgen TD (2001) Analysis of relative gene expression data using real-time quantitative PCR and the 2(-Delta Delta C(T)) Method. Methods 25:402-408 
33. Lu K, Song Y, Zeng R (2021) The role of cytochrome P450-mediated detoxification in insect adaptation to xenobiotics. Curr Opin Insect Sci 43:103-107

34. Martelli F, Zhongyuan Z, Wang J, Wong CO, Karagas NE, Roessner U, Rupasinghe T, Venkatachalam K, Perry T, Bellen HJ, Batterham P (2020) Low doses of the neonicotinoid insecticide imidacloprid induce ROS triggering neurological and metabolic impairments in Drosophila. Proc Natl Acad Sci U S A 117:25840-25850

35. Matsuda K, Ihara M, Sattelle DB (2020) Neonicotinoid Insecticides: Molecular Targets, Resistance, and Toxicity. Annu Rev Pharmacol Toxicol 60:241-255

36. Morakchi S, Maiza A, Farine P, Aribi N, Soltani N (2005) Effects of a neonicotinoid insecticide (acetamiprid) on acetylcholinesterase activity and cuticular hydrocarbons profil in German cockroaches. Commun Agric Appl Biol Sci 70:843-848

37. Nebot C, Moutet M, Huet P, Xu J-Z, Yadan J, Chaudiere J (1993) Spectrophotometric assay of superoxide dismutase activity based on the activated autoxidation of a tetracyclic catechol. Anal Biochem 214:442-451

38. Palli SR (2020) CncC/Maf-mediated xenobiotic response pathway in insects. Arch Insect Biochem Physiol 104:e21674

39. Parkinson RH, Little JM, Gray JR (2017) A sublethal dose of a neonicotinoid insecticide disrupts visual processing and collision avoidance behaviour in Locusta migratoria. Sci Rep 7:936

40. Parkinson RH, Zhang S, Gray JR (2020) Neonicotinoid and sulfoximine pesticides differentially impair insect escape behavior and motion detection. Proc Natl Acad Sci U S A 117:5510-5515

41. Peachey LD (1958) Thin sections. I. A study of section thickness and physical distortion produced during microtomy. J Biophys Biochem Cytol 4:233-242

42. Reynolds ES (1963) The use of lead citrate at high $\mathrm{pH}$ as an electron-opaque stain in electron microscopy. J CELL BIOL 17:208-212

43. Scandalios JG (2005) Oxidative stress: molecular perception and transduction of signals triggering antioxidant gene defenses. Braz J Med Biol Res 38:995-1014

44. Shapiro HM (2005) Practical flow cytometry. John Wiley \& Sons

45. Smith IK, Vierheller TL, Thorne CA (1988) Assay of glutathione reductase in crude tissue homogenates using 5, 5'-dithiobis (2-nitrobenzoic acid). Anal Biochem 175:408-413

46. Suchail S, De Sousa G, Rahmani R, Belzunces LP (2004) In vivo distribution and metabolisation of 14C-imidacloprid in different compartments of Apis mellifera L. Pest Manag Sci 60:1056-1062

47. Tahmasebi P, Javadpour F, Sahimi M (2015) Three-dimensional stochastic characterization of shale SEM images. Transp Porous Media 110:521-531

48. Thompson DA, Lehmler HJ, Kolpin DW, Hladik ML, Vargo JD, Schilling KE, LeFevre GH, Peeples TL, Poch MC, LaDuca LE, Cwiertny DM, Field RW (2020) A critical review on the potential impacts of neonicotinoid insecticide use: current knowledge of environmental fate, toxicity, and implications for human health. Environ Sci Process Impacts 22:1315-1346 
49. Tomizawa M, Casida JE (2005) Neonicotinoid insecticide toxicology: mechanisms of selective action. Annu Rev Pharmacol Toxicol 45:247-268

50. Wang H, Lu Z, Li M, Fang Y, Qu J, Mao T, Chen J, Li F, Sun H, Li B (2020) Responses of detoxification enzymes in the midgut of Bombyx mori after exposure to low-dose of acetamiprid. Chemosphere 251:126438

51. Wang H-S, Zhou C-S, Guo W, Kang L (2006) Thermoperiodic acclimations enhance cold hardiness of the eggs of the migratory locust. Cryobiology 53:206-217

52. Wang X, Anadon A, Wu Q, Qiao F, Ares I, Martinez-Larranaga MR, Yuan Z, Martinez MA (2018) Mechanism of Neonicotinoid Toxicity: Impact on Oxidative Stress and Metabolism. Annu Rev Pharmacol Toxicol 58:471-507

53. Wood TJ, Goulson D (2017) The environmental risks of neonicotinoid pesticides: a review of the evidence post 2013. Environ Sci Pollut Res Int 24:17285-17325

54. Zhang L, Wang X, Cueto R, Effi C, Zhang Y, Tan H, Qin X, Ji Y, Yang X, Wang H (2019) Biochemical basis and metabolic interplay of redox regulation. Redox Biol 26:101284

\section{Figures}
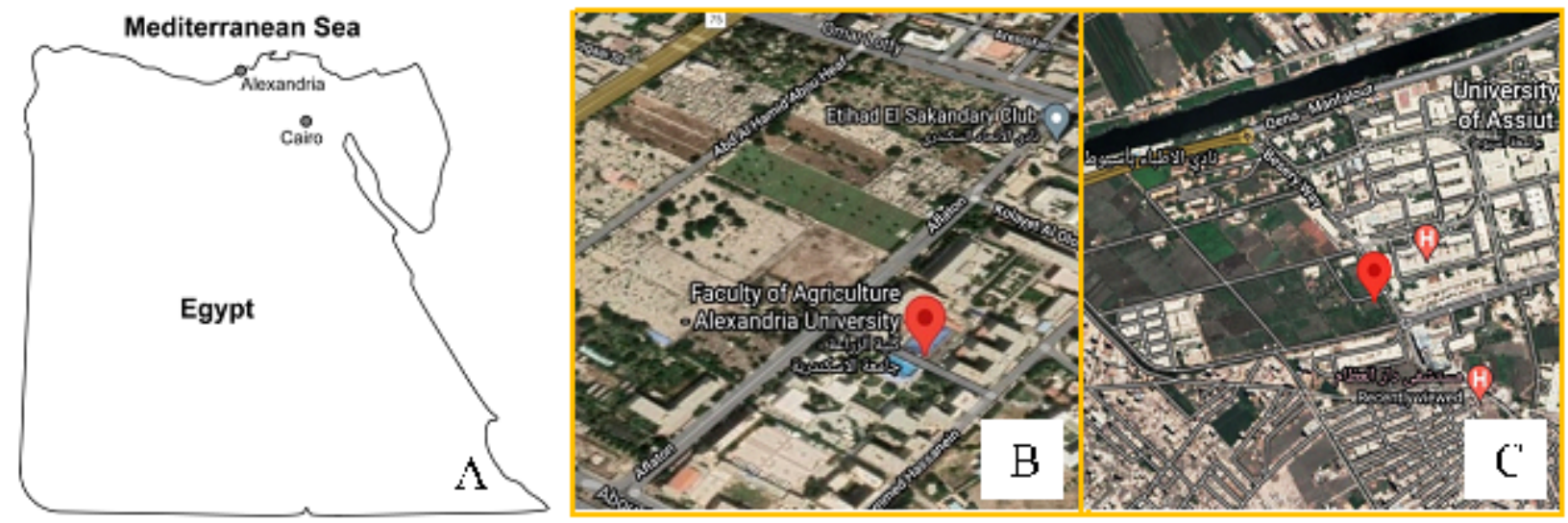

Figure 1

Alexandria lies on the coast of Egypt at the Mediterranean See (A). According to the Köppen-Geiger system it has a desert climate (BWh, $181 \mathrm{~mm}$ precipitation per year) with an average temperature of $20.8^{\circ} \mathrm{C}$. Map of Alexandria Governorate (control site) (B) and Assuit Governorate (contaminated site) (C). 


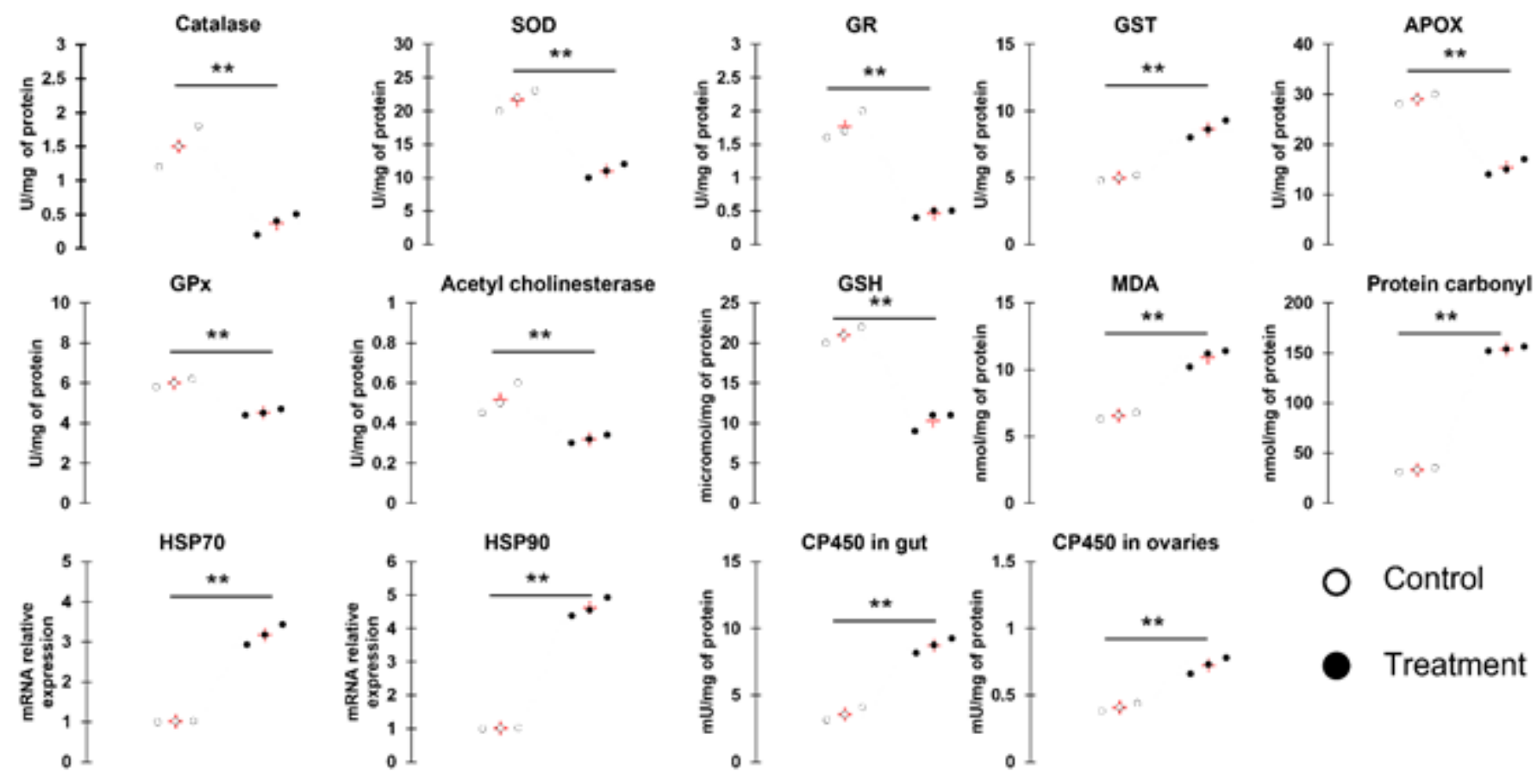

Figure 2

Biochemical analyses of ROS metabolism. 


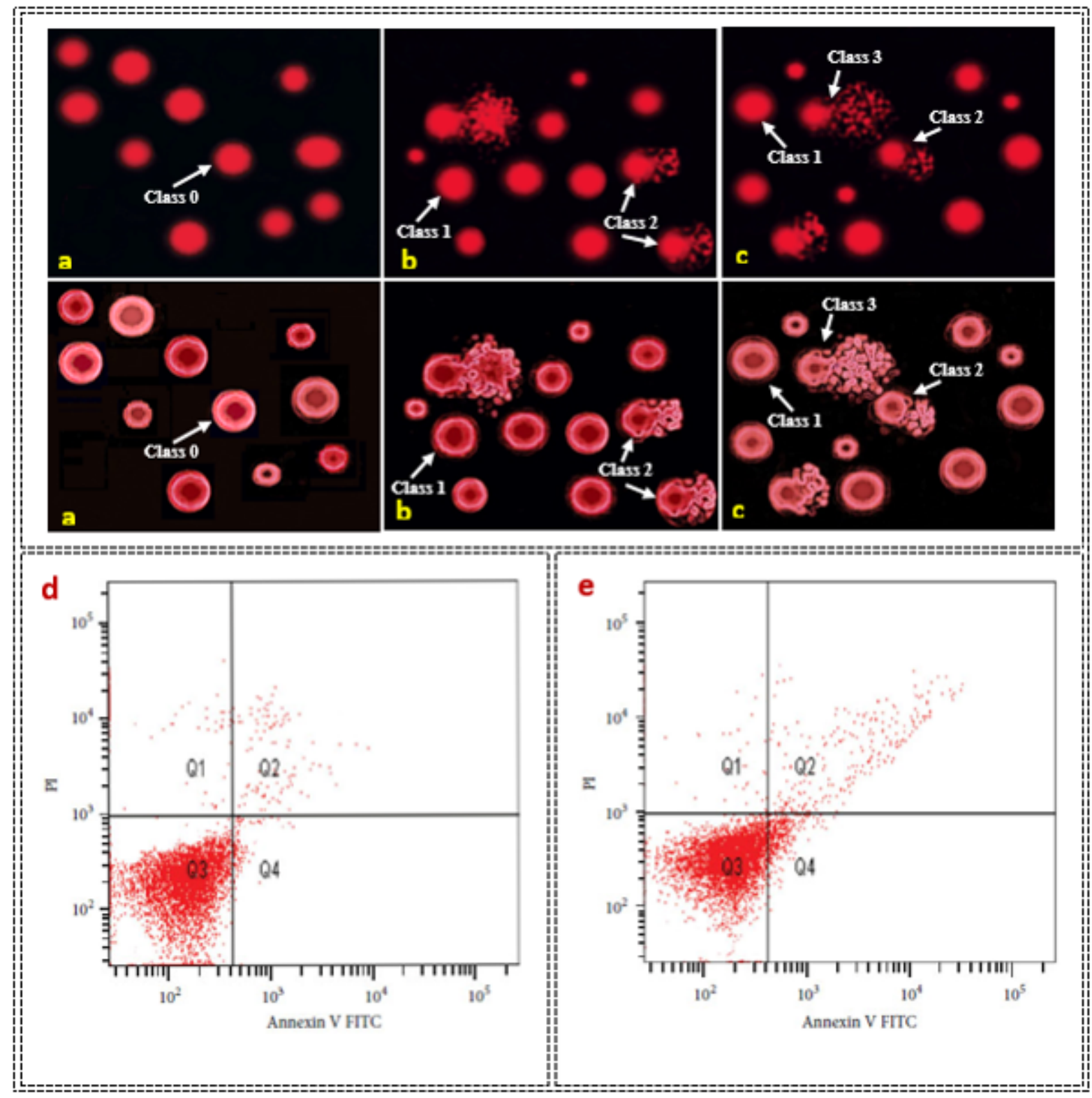

\section{Figure 3}

The gut tissues of locust showing DNA damage using the comet assay from control (a) and polluted area (b \& c) and flow cytometric analysis of annexin V-FITC and PI-staining from control (d) and polluted area (e). Q1: necrotic cells, Q2: late apoptotic cells, Q3: living cells, Q4: early apoptotic cells. The Y-axis represents the PI-labeled population, whereas the X-axis represents the FITC-labeled Annexin $\vee$ positive cells. 


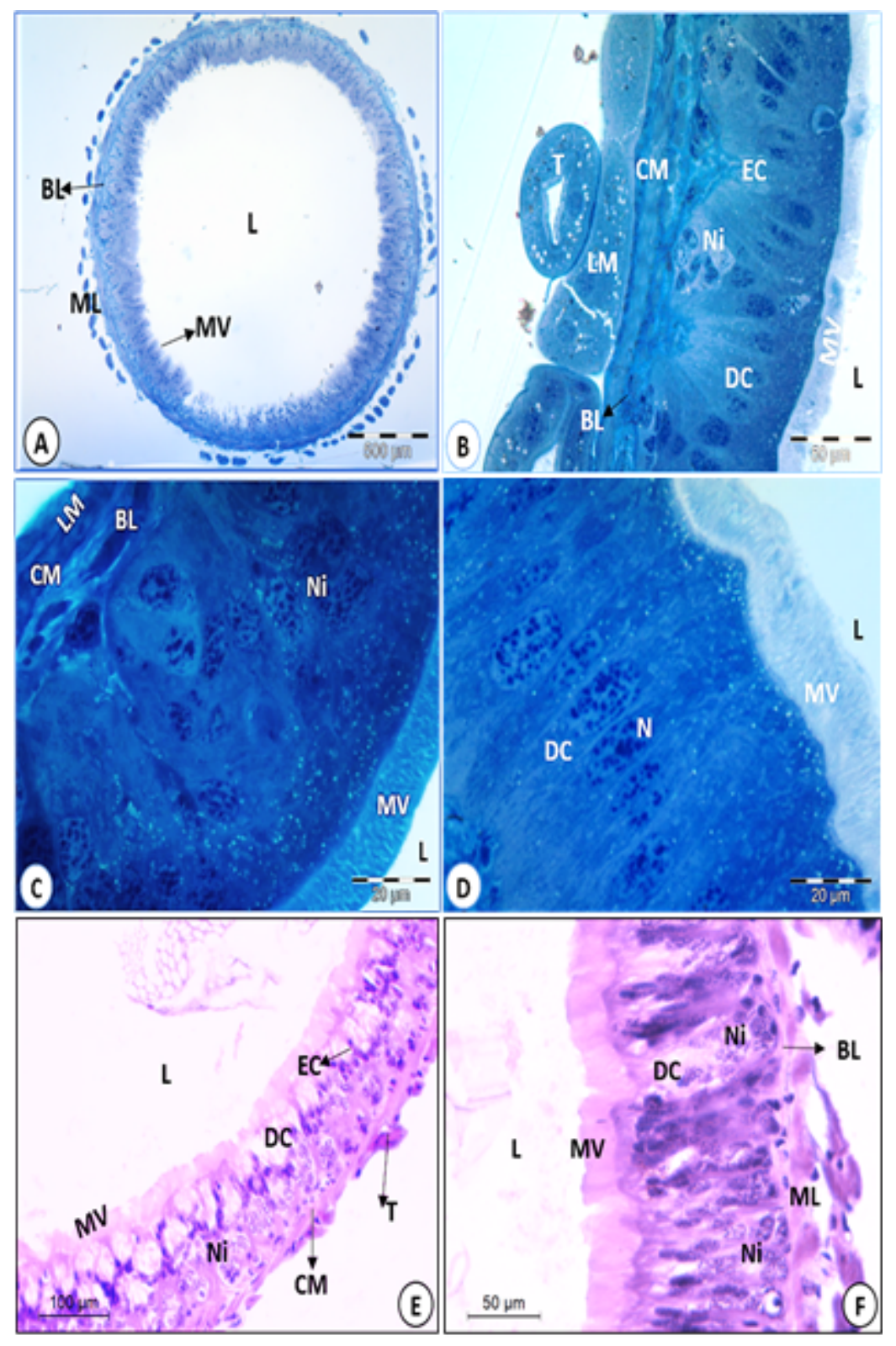

Figure 4

Light micrographs of the transverse section of the healthy control desert locust midgut region. A - D): Semithin cross-sections (toluidine blue stain) and E\&F): Histological sections (hematoxylin and eosin stain): The epithelial is intact, showing digestive cells (Dc) with regular columnar cells and spherical nucleus $(\mathrm{N})$; the apical region shows well-developed elongated microvilli (MV) border toward the midgut lumen (L); regenerative cells nidi (Ni); endocrine cell (EC). Note: muscle layer (circular muscles (CM), longitudinal muscles (LM)); basal lamina (BL) and trachea $(\mathrm{T})$. 

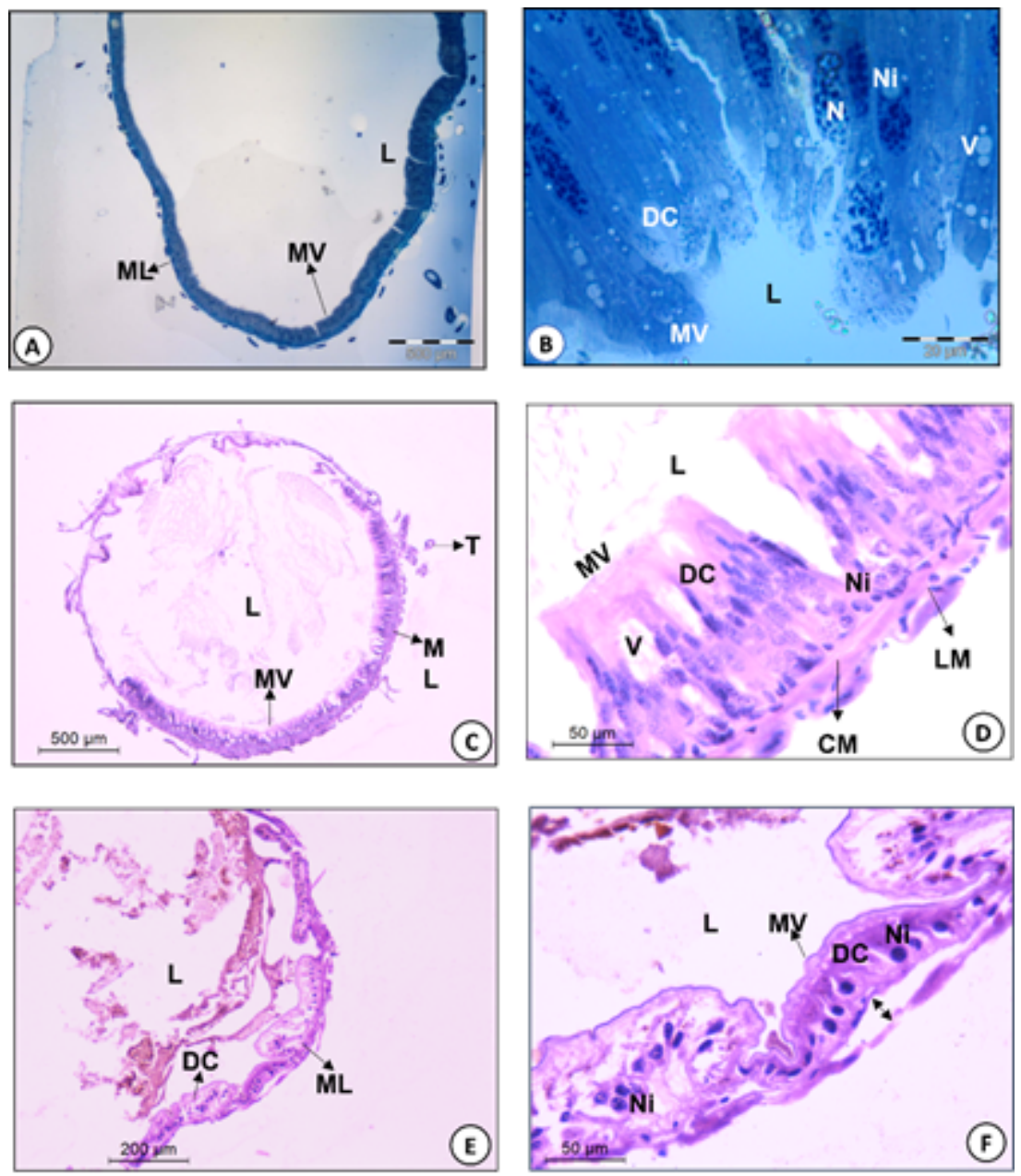

Figure 5

Light micrographs of the transverse section of the polluted desert locust midgut region. (A\&B) Semithin cross-sections (toluidine blue stain): digestive cells (Dc); disintegrating nidi (Ni) with a few nuclei (N). (CF) Epithelium (hematoxylin and eosin stain): part of the midgut where the epithelium has been completely destroyed cell debris is observed in the midgut lumen $(L)$; muscle layer $(M L)$ consists of circular muscles (CM), longitudinal muscles (LM). Note detachment of the epithelium from the basal membrane; disorganization of columnar cells with vacuoles (V) and disintegrating nidi (Ni); Distorted microvilli (MV). 


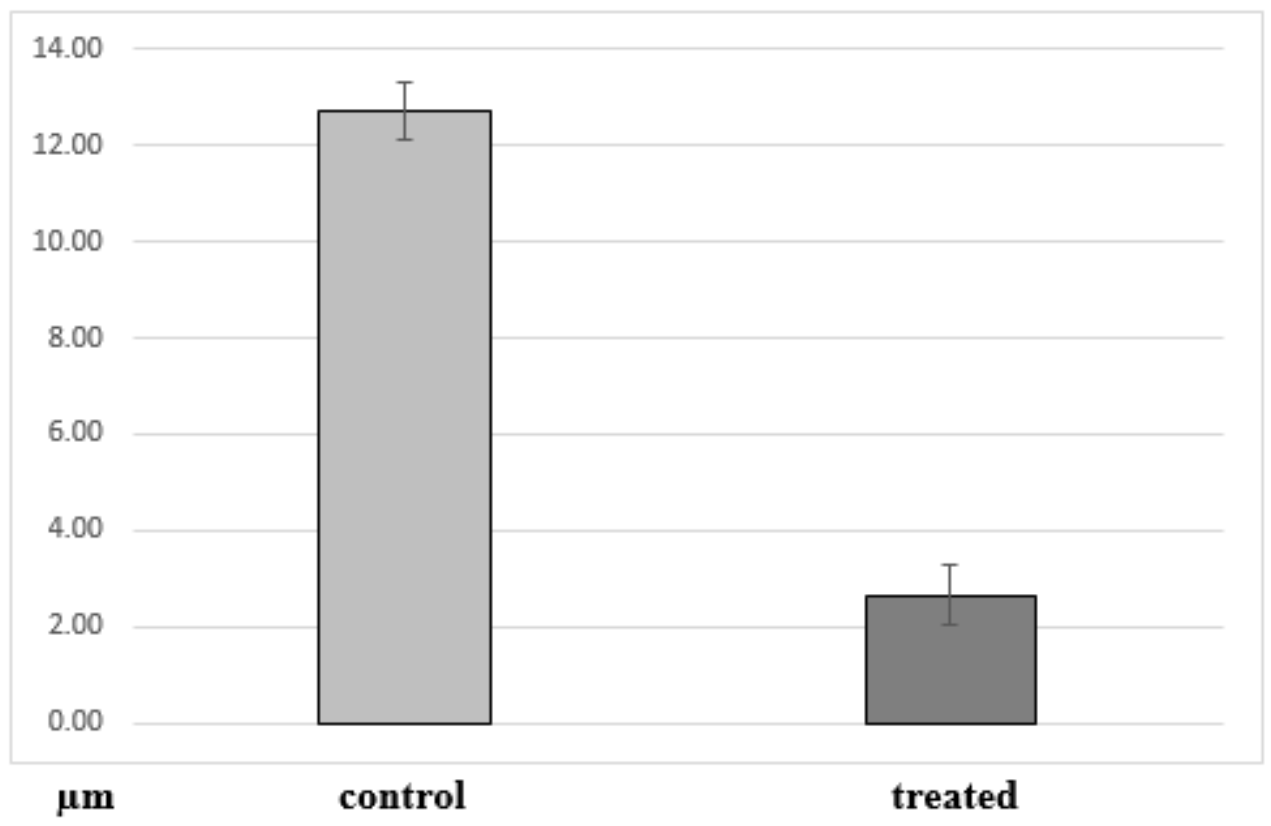

Figure 6

Morphometric measurements of villus length. The length difference is significant according to a Student's t-test $(p=5 \times 10-5) ; n=5 /$ group.
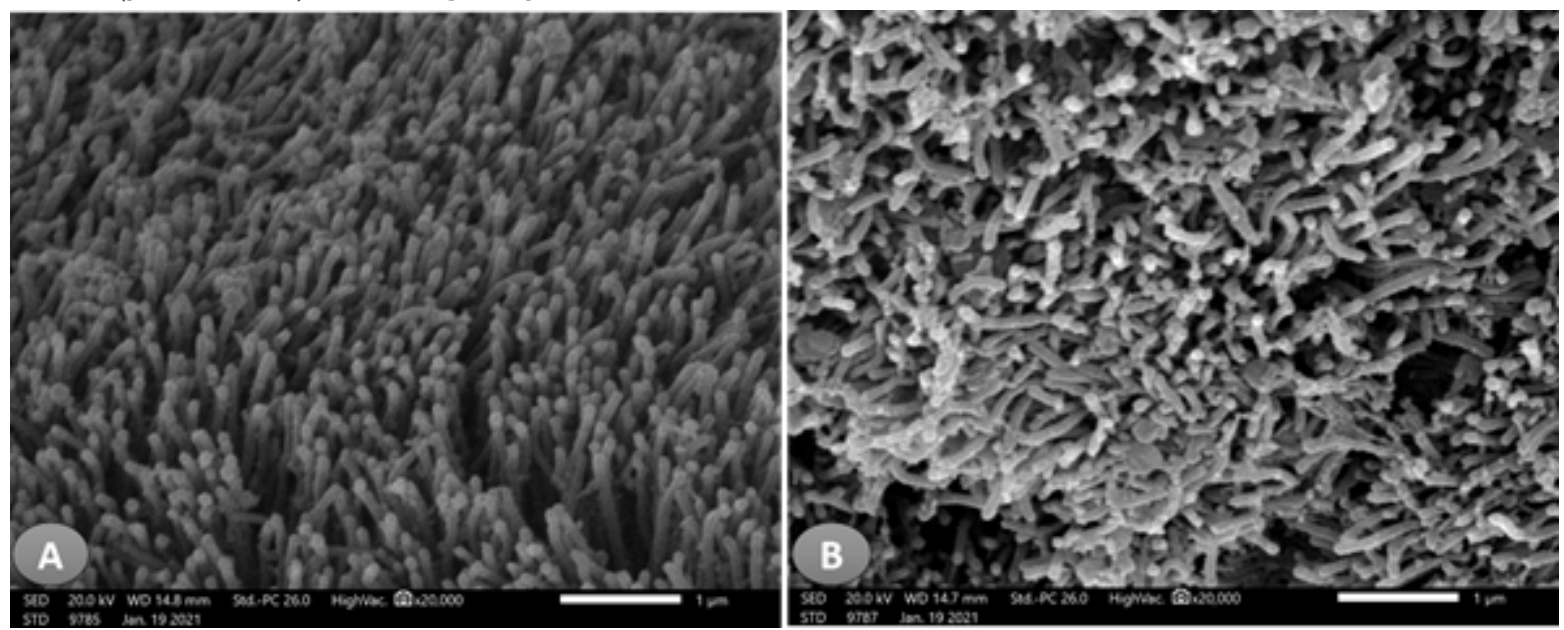

Figure 7

Scanning electron microscopy of the surface view of desert locust midgut region: A) Inner surface of healthy control midgut shows the microvilli (MV) was arranged as a mesh on and between cells and extending toward the lumen $(L)$. B) The inner surface view of polluted locus midgut shows cells with irregular apical surface microvilli (MV). Scale bar $548 \mu \mathrm{m}$. 


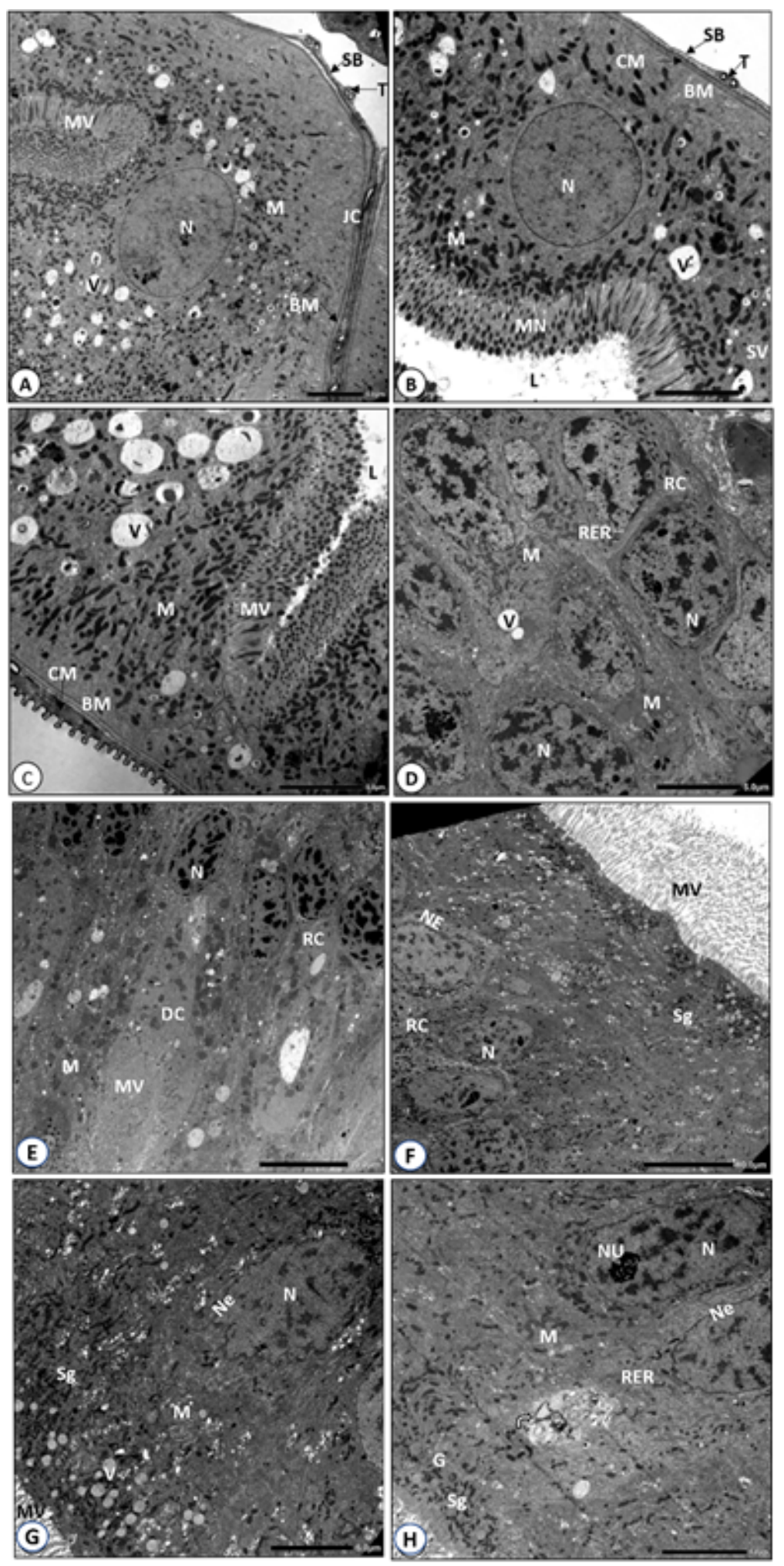

\section{Figure 8}

Transmission electron microscopy of control and treated locust midgut epithelium: A-C) showing basal and supranuclear region of the digestive cells. (D) showing nidi of regenerative cells with normal nucleus and regular nuclear envelope. Notice: The well-defined basement membrane (BM); junctional complex $(\mathrm{JC})$; circular muscle (CM); nucleus $(\mathrm{N})$ with well-developed nucleoli; vesicles containing granular material (V); rough endoplasmic reticulum (RER); mitochondria (M); secretory vesicles (SV); abundant microvilli 
(Mv) extending into the lumen (L); serosal barrier (SB); tracheole(T). (E\&G) Digestive cells (DC) with disrupted microvilli (Mv), swollen shape and distribution of the mitochondria (M), multivesicular bodies $(\mathrm{Mb}) .(\mathrm{F} \& \mathrm{H})$ regenerative calls with nucleus $(\mathrm{N})$; eccentric and segregated nucleolus $(\mathrm{Nu})$ and heterochromatin distributed within the nucleoplasm and along the irregular nuclear envelope $(\mathrm{Ne})$. notice: dilated rough endoplasmic reticulum (RER); Golgi apparatus (G) secretory granules (Sg); myelinated fibers (curved arrow). 